\title{
Byens arabesk
}

\author{
Robert Musils Wien
}

\section{Peter Nielsen}

Som indgang til sin store roman Manden uden egenskaber priviligerer Robert Musil sin læser med et næșten kosmisk overblik, før der zoomes ind på et næsten tilfældigt sted: Wien en augustdag i 1913:

Over Atlanterhavet befandt sig et barometrisk lavtryk; det vandrede østpå mod et højtryk liggende over Rusland og røbede endnu ikke tilbøjelighed til at vige nord om dette. Isotermer og isoterer gjorde deres skyldighed. Lufttemperaturen stod i et ordensmæssigt forhold til årets middeltemperatur og til den aperiodiske månedlige temperatursvingning. Solens og månens op- og nedgange, månens, Venus' og Saturnringens faser og mange andre betydningsfulde fænomener svarede til forudsigelserne i de astronomiske årbøger. Vanddampen i luften havde sin højeste spændkraft, og luftens fugtighed var lav. Med en vending, der ganske godt betegner det faktiske, skønt den er lidt gammeldags: Det var en smuk augustdag i 1913 (Musil 1994, 1/13).1

Som vi erfarer i det følgende er det Wien, der kommer til syne et sted midt imellem Atlanterhavet og Rusland. Efter dette overblik synker vi ned på gadens niveau midt i byens brølende kaos:

Biler susede fra smalle, dybe gader ud på lyse, flade pladser. Fodgængermørke dannede skyagtige snore. Hvor kraftigere fartstreger kørte tværs gennem deres løse hast tyknede de, rislede siden hurtigere og havde efter få svingninger deres regelmæssige puls igen. Hundreder af toner var tvundet sammen til en trådet støj, hvorfra enkelte spidser ragede frem, langs hvilken skarpe kanter løb og atter udjævnedes, hvorfra klare toner skilte sig ud og flagrede bort (Musil 1994, 1/13). 
Med denne bevægelse fra et kosmisk niveau til byens gadeplan er der imidlertid ikke kun tale om en klassisk bevægelse fra overblik til fortabelse og forvirring, ${ }^{2}$ fra orden til uorden, selvom det antydes i skiftet fra de 'ordnede' meteorologiske forhold til byens uordentlige mylder.

Hos Musil er de to niveauer ikke entydigt kontrasteret, men er derimod karakteriseret ved visse strukturelle lighedspunkter. Det handler kort sagt om, at orden og uorden, det almene og de kaotiske singulariteter, genfindes på begge de to niveauer som en sælsom og uudgrundelige relation. Denne sælsomme og uudgrundelige relation er en utrolig dynamisk kraft knyttet til det litterære eller æstetiske i Musils byiscenesættelse. Det kosmiske og det lokale niveau afspejler ikke nødvendigvis hinanden, men udgør en urolig, vibrerende relation, som vores bevidsthed ikke umiddelbart har nogle smutveje til at begribe, og som den derfor står overfor med fuldstændig lammelse, indtil den påtvinges et logisk system. At fokusere på denne urolige relation er i en vis forstand at hæfte sig ved det litterære i byiscenesættelsen.

Musil bruger ikke det æstetiske til at løfte sig op over virvarret og konstruere eller manipulere et overblik over den moderne storby. Han bruger det i stedet for til en anden erkendelse af de mange små hændelser i en moderne storby som Wien; som ikke med det samme underkastes en bestemt betydning.

Lad mig først kigge på Musils iscenesættelse af det kosmiske niveau: Ved nærmere eftersyn afsløres det, at den meteorologiske beskrivelses tilsyneladende videnskabelige, upersonlige nøgternhed (af: „Det var en smuk augustdag i 1913“) ikke fuldstændigt har formået at udviske det personlige eller menneskelige fra sin stil. Det er bemærkelsesværdigt, at et lavtryk kan „røbe tilbøjelighed" og at isotermer og isoterer "gjorde deres skyldighed". Det er udtryk eller vendinger, som ikke hører hjemme i en streng videnskabelig beskrivelse, men snarere karakteriserer noget meget menneskeligt. Med andre ord: den videnskabelige diskurs antropomorfiseres. ${ }^{3}$ Disse fysiske fænomener tilskrives menneskelige egenskaber som et slags forsøg på at trække dem ind i en genkendelig og forståelig verden; som en bestræbelse på at tilpasse dem vores erfarings billeder.
Dette er imidlertid kun det ene. Det er lige så vigtigt at være opmærksom på forholdet mellem det singulære (de enkelte meteorologiske faktorer - eller netop singulariteter) og den overordnede, statistiske orden som singulariteterne indpasses i eller indordnes under: „Lufttemperaturen stod i et ordensmæessigt forhold til årets middeltemperatur..." og „Solens og månens op- og nedgange, månens, Venus' og Saturnringens faser og mange andre betydningsfulde fænomener svarede til forudsigelserne i de astronomiske årbøger".4

Det singulære er bemærkelsesværdigt nok allerede indføjet i en orden. Men den logik, som singulariteterne derved bøjes ind mod, er i virkeligheden en kolossal abstraktion og samtidig en forblindelse. Den er en rent statistisk størrelse, som på ingen måde er apriorisk nødvendig, selvom den bagefter tager sig sådan ud.

Musil antyder her det uudgrundelige forhold, der består mellem tilfældet (det singulære) og nødvendigheden (det almene). I hans fremstilling handler det om at komme bag om den statistiske orden og se forholdet som en produktiv udveksling, som en distribution af mulige betydninger og mulige verdener. ${ }^{5}$

Det er selvfølgelig ikke uden en vis ironi, at Musil i indledningen netop vælger meteorologien til at iscenesætte dette forhold mellem det singulære og det almene. I meteorologien er antallet af singulariteter så enorm, at en eksakt betegnelse over deres position og deres hastighed er helt umulig. ${ }^{6}$ Begreber som f.eks. "temperatur" , „vanddampens spændkraft", , ,fugtighed " er begreber uden egenskaber, begreber, der ikke refererer til én singulær fysisk situation, men til en distribution af mulige situationer, hvoraf kun en enkelt realiseres. ${ }^{7}$

I meteorologien er den kausale relation mellem de singulære eller lokale betingelser og den almene lov, der normalt tillader os uproblematisk at skifte mellem niveauerne, således brudt fuldstændigt op og dækket til igen af slørende sproglige vendinger eller antropomorfiseringer. Den fuldkomne sammenhæng mellem alle faktorer og niveauer e̊r afløst af en lammende afgrundsdyb fortvivlelse. For der fremgår intet af de forudgivede beting- 
elser, sådan som det hedder i kapitlets titel. Der fremgår intet bestemt.

At der intet bestemt fremgår af de forudgivede betingelser er en erkendelsesmæssig provokation, en lammende følelse. At der intet bestemt fremgår, gør det nødvendigt at omvurdere forholdet mellem de singulære tilfældigheder (eller forudgivede betingelser) og den almene nødvendighed. Dette kan ikke blot reduceres til abstrakte overvejelser over meteorologisk forhold, men er noget som vedrører selve vores sanselige erfaring af det, der i byens kaotiske strøm ikke entydigt passer ind i en (begrebslig) orden, af det der rager lidt frem, skiller sig ud, eller af det der pludselig slår på tværs i en given orden. Byen står med andre ord hos Musil i erkendelsens tjeneste. I byens rum formes vores sanselige erfaring af verden. I storbymenneskets bevidsthed ligger byens historiske og kulturelle strukturer aflejret og befinder sig i stadig konflikt med nye strukturer.

Den kausale relation mellem det enkelte og det almene er betingelsen for, at vores sansning af verden kan blive gjort til erfaring. At den kan systematiseres. Det svarer til det, Musil kalder bevidsthedens vaneindstillinger, dens faste skabeloner eller kageforme. Som en strategi over for disse kageforme ser han i mere overordnet forstand kunstens rolle som det, han har kaldt at ødelægge ligevægten for vores virkelighedsopfattelse („Gleichgewichtsstörung des Wirklichkeitsbewußtsein"). 8 Kunstens rolle forstår han som en konstant fornyelse og omformning af vores forudbestemte billede af verden.

Hvis det singulære tilkendes selvstændig betydning, og hvis den litterære fremstilling skaber mulighed for, at det kan tilnærmes erkendelsen, vil fokuseringen på det singulære, dets fraspaltning ${ }^{9}$ eller isolering fra dets sædvanlige begrebslige sammenhæng, gøre det muligt i en vis forstand at ødelægge den orden, det singulære for forudbestemt til.

På gadeplan finder vi en tilsvarende relation mellem det singulære og det almene som på det kosmiske. Byen beskrives som et myldrende inferno af lyd og bevægelse. Byens støj er karakteriseret ved både kaos og orden: „hundreder af toner var tvundet sammen til en trådet støj, hvorfra enkelte spidser ragede frem, langs hvilken skarpe kanter løb og atter udjævnedes, hvorfra klare toner skilte sig ud og flagrede bort". Nogle toner udjævnes, andre skiller sig ud og flagrer bort. Det regelmæssige ledsages af rebelske singulariteter, der hele tiden truer med at afspore situationen eller bringe den ud af ligevægt.

\section{Sansning og system}

Skønt støjens særpræg ikke var til at beskrive, ville et menneske, selv efter årelang fraværelse med lukkede øjne kunne høre på den, at han befandt sig i rigshoved- og residensstaden Wien. Ligesom mennesker kan byer kendes på gangen. Når den pågældende åbnede øjnene, ville han fornemme det af den måde, hvorpå bevægelsen i gaderne svinger, længe før han fandt ud af det ved hjælp af en eller anden karakteristisk detalje. Og skulle det bare være noget, han bildte sig ind, gør det heller ikke noget. Overvurderingen af spørgsmålet om, hvor man befinder sig, stammer fra hordetiden, da man måtte mærke sig foderstederne. Det ville være vigtigt at vide, hvorfor man, når talen er om en rød næse, ganske unøjagtigt lader sig nøje med, at den er rød, og aldrig spørger, hvilken særlig rød farve den har, skønt det kunne udtrykkes nøjagtigt på mikromillimeter ved hjælp af bølgelængden; hvorimod man, når det drejer sig om noget så langt mere kompliceret som en by man opholder sig i, altid vil vide helt nøjagtigt, hvilken særlig by det er. Det afleder opmærksomheden fra vigtigere ting (Musil 1994, 1/13-14).

Wien kendes på sin gang. At genkende den specifikke by består ikke blot i at genkende en karakteristisk detalje eller i at akkumulere og sammenbinde byens enkelte dele, huse, gader, seværdigheder, kort sagt punkterne i et forudgivet rum. Genkendelsen er noget meget mere vanskeligt definerbart: byen sanses og genkendes på sin rytme - en rytme som giver en slags genklang i den menneskelige bevidsthed. Hos Musil er den sanselige erfaring eller genkendelsen af byen ikke længere afhængig af et rum med faste koordinater, af et rum med et bestandigt centrum og periferi, men kan ske ud fra vilkårlige punkter i byens virvar - og forsvinde bort igen, når disse sansninger blander sig med andre og skaber nye rum 
Disse sidste betragtninger over rummets funktion er inspireret af udviklingen i fysikken og filosofien i. Wien fra slutningen af forrige århundrede, især af filosoffen og fysikeren Ernst Machs opgør med den klassiske fysik og hans kritik af den ene af Kants aprioriske anskuelsesformer og betingelser for erkendelsen, nemlig rummet. Mach nedbrød rummet som en apriorisk betingelse for al aktivitet, og han genindførte rummet som det, han har kaldt et "system af sanseindtryk", 10 der hele tiden kan opløses igen.

Ligesom den klare grænse mellem jeg'et og omverdenen er ophævet i Machs tænkning og fremstillet som en bestandig proces af udveksling og distribution, er rummet noget som i en evig proces bliver til og udviskes igen. I naturlig forlængelse af denne jeg- og rumopfattelse kunne man sige, at den antropocentriske verdensanskuelse mister sin gyldighed fra og med Mach. Det er selvfølgeligt og banalt, at sansningen af byen, af rummet er egocentrisk. Men at den er egocentrisk, er ikke det samme som at gøre dette jegs sansning til et midtpunkt for hele verden.

Det er meget oplagt, at ophævelsen af det antropocentriske perspektiv samtidig skulle være fremprovokeret af den moderne storbys hastige vækst. Antropocentrisme har nemlig at gøre med et vist provinsielt sindelag, som ifølge den spanske kulturfilosof Ortega y Gasset:

har sin årsag i en optisk fejltagelse. Det glemmer at det anskuer universet fra en excentrisk position, og tror det er universets midtpunkt. Alle den provinsielles meninger fødes gale, fordi de udgår fra et pseudocentrum. Storbymennesket ved derimod at dets by, hvor stor den end er, kun er et punkt i universet, en afkrog. Og det ved også at verden ikke har noget centrum, og at det derfor i alle vores værdidomune er nødvendigt at tage hensyn til det særlige perspektiv, hvorunder enhver af os ser virkeligheden. ${ }^{11}$

Antropocentrismen eller det provinsielle sindelag er i forhold til den moderne verden, som Gasset siger, en galskab, en optisk fejltagelse. Det er den, fordi den afspejler en klassisk, statisk rumopfattelse. I modsætning hertil har det moderne storbymenneske tabt et statisk midtpunkt og en strategisk overlegen position i storbyens kraftfelt.

Den moderne storbys ændrede livsrytme, hyppigheden og den hurtige veksel af sanseinput, præger ikke kun storbymenneskets erfaringsstruktur. Det påvirker selvfølgelig også litteraturens virkelighedsbearbejdning og menneskefremstilling. Det moderne storbymenneske er udsat for et sandt bombardement af sanserne. Det er et vindue mod en kaotisk omverden, sådan som Musil ironisk fremstiller det med sin hovedperson Ulrich i romanens andet kapitel:

Han stod bag et af vinduerne, så gennem haveluftens sartgrønne filter ud på den brunlige gade og havde i de sidste minutter med uret i hånden talt de biler, de hestekøretøjer, de sporvogne og de på denne afstand udvaskede fodgængeransigter, der fyldte blikkets net med piskende travlhed; han bedømte hastighederne, vinklerne, de levende kræfter i fremadbevægede masser, som lynhurtigt trækker øjet efter sig, holder det fast, slipper det, som i et tidsrum, der ikke findes mål for, tvinger opmærksomheden til at stemme sig imod dem, rive sig løs, springe til den næste og kaste sig efter den; kort sagt, efter en stund at have regnet i hovedet stak han leende uret $i$ lommen og fastslog, at hans forehavende var meningsløst. - Kunne man måle opmærksomhedens spring, øjenmusklernes præstationer, sjælens pendulbevægelser og alle de anstrengelser; et menneske må fuldføre for at holde sig oprejst $i$ en gades strømmende bevægelse, ville der formodentlig - sådan havde han tænkt og legende forsøgt at beregne det umulige - fremkomme en størrelse, i sammenligning med hvilken den styrke, Atlas behøver for at stemme verden op, er ringe, og man ville kunne måle, hvilken uhyre præstation der i vore dage ydes af et menneske, som slet intet laver (Musil 1994, 1/16-17).

Ulrichs forsøg på at bringe sig på afstand og måle byens strømmende bevægelse, bringe den på formel, er naturligvis et absurd foretagende. Som en mand uden egenskaber kan han give pokker $\mathrm{i}$ alle forestillinger om selvopretholdelse og gode karakteregenskaber og give sig hen i dens strømmen som en anden flanør. Det underlige .ved Ulrich er, at han ikke bare lader sig føre med af strømmen, men samtidig hele tiden forsøger at bringe rationalitet ind i forhold til de rebelske singulariteter. Der er imidlertid tale om en rationalitet, som ikke er deduktiv, men snarere 
induktiv. I Ulrichs figur falder udvekslingen mellem jeg'et og den sansede omverden aldrig til ro, ligesom romanhandlingen heller ikke kan gøre det. Den slynger sig af snirklede omveje, fortaber sig og finder tilbage til et lidt forskudt udgangspunkt. Det lykkes ikke nogen person i romanen at forvandle den kaotiske sansning til en subjektiv artikuleret og systematiseret sansning. Ikke engang Ulrich. Han fungerer ikke som et syntetiserende midtpunkt for handlingen og for erkendelsen, men som en transithal for funktioner, bevægelse og sanseimpulser. Han er garant for at skildre en verden i bestandig bevægelse.

I modsætning til Ulrich søger romanens øvrige personer i fortvivlelse og som beskyttelse mod sansernes kaotiske verden kontakt med et centrum, med et midtpunkt, der skal forsyne det moderne relative rum med faste vægge. Men dette midtpunkt er i virkeligheden en forblindelse eller en afskærmning af synet, der blokerer for at erfare tilværelsens metafysiske niveau. Metafysisk er blot et andet udtryk for følelsen af aldrig at have fast jord under fødderne eller have himlens klare runding over hovedet; det er også et udtryk for erkendelsesmæssigt at have mistet enhver konstant af etisk art. Eller udtrykt på en anden måde, at ens tilværelse er kastet $i$ noget andet og mere grundlæggende. Orienteringen mod et midtpunkt er i virkeligheden et udtryk for storbymenneskets „provinsielle sindelag”.

Når Musil vælger at relativere Wien som det konkrete udgangspunkt for sin romanhandling: „Der skal altså ikke lægges særlig vægt på byens navn”, fordi „Det afleder opmærksomheden fra vigtigere ting", skyldes det interessen for det mere almene. En alt for tydelig signifikation af Wien afleder opmærksomheden fra det som er Musils særlige interesse med byrepræsentationen. For hvilken rolle spiller den faktiske by for Musils litterære iscenesættelse? Hans interesse for den konkrete by bunder i interessen for det mere almene ved det konkrete. Hans opmærksomhed på det almene eller generelle ved storbyen knytter Musil til en grundlæggende kulturel erfaring eller til et billede på kulturens evige forvandlingsproces, som f.eks. i det følgende:
Som alle store byer byer bestod den af uregelmæssighed, skiften, fremadgliden, ikkeholdentrit, sammenstød af ting og anliggender, derimellem bundløse punkter af stilhed, af baner og ubanet, af et stort rytmisk slag og den evige forstemning og forskydning af alle rytmer mod hinanden, og lignede alt $i$ alt en kogende boble, der hviler i et kar af huses, loves, forordningers og historiske overleveringers holdbare stof (Musil 1994, 1/14).

Wien er i dette billede blevet til en boble (en tilstand, et rum), der er betinget af det stof den hviler i. Wien er blevet til en dynamisk proces med nogle bestemte kendetegn. Byen beskrives som en dobbelthed af tilstand og proces, af det regelmæssige og det uregelmæssige. I billedet af byen som et kar er Wien ikke længere blot Wien en augustdag i 1913, men et øjebliks tilstand i det kosmiske åndedrag. Wien er ikke længere et klart afgrænset geografisk rum, men snarere et historisk-kulturelt rum, der forvandles som resultat af den bestandige konfrontation og brydning af det nye og det overleverede. Enhver kultur er for Musil karakteriseret ved en sådan relation mellem tilstand og forvandling. I den sanselige erfaring af den moderne verden (som byen er mønster på) handler det om, hvorvidt vi lever i en sanselig afskærmning i forhold til begribelsen af de rebelske singulariteter, eller hvorvidt vi lever midt i forvandlingen og forsøger erkendelsesmæssigt at komme på højde med den.

\section{Ulykkens singularitet}

De to mennesker, der heri [byen; boblen] gik ad en bred, befærdet gade, havde naturligvis slet ikke det indtryk [...] Antager man, at de hed Arnheim og Ermelinda Tuzzi, hvilket dog ikke er tilfældet, for fru Tuzzi befandt sig $i$ august måned $i$ Bad Aussee ledsaget af sin mand og dr. Arnheim endnu i Konstantinopel, står man over for den gåde, hvem de var. Livfulde mennesker oplever hyppigt den slags gåder på gaden. De løser sig på bemærkelsesværdig vis ved, at man glemmer dem, såfremt man ikke i løbet af de næste halvtreds skridt kommer på, hvor det er, man har set de to før. Disse to standsede nu pludselig deres skridt, fordi de bemærkede et opløb lidt længere fremme. Et øjeblik forinden var noget sprunget ud af række, en bevægelse slog på tværs; noget havde drejet sig, var skreddet sidelæns, en tung, pludseligt bremset lastvogn, viste 
det sig nu da den stod strandet med det ene hjul på kantstenen. Som bierne om flyvehullet havde folk i et nu sat sig fast om en lille plet, de holdt fri i deres midte. Her, grå som indpakningspapir, stod chaufføren, der var kommet ned fra sin vogn, og forklarede ulykken med grove fagter. De tililendes blikke rettede sig mod ham og sank derpå forsigtigt ned i hullets dyb, hvor man havde lagt en mand, der lå som død, ind til fortovskanten [...] Damen og hendes ledsager var også trådt nærmere og havde hen over hoveder og bøjede rygge betragtet den liggende mand. Så trådte de tilbage og tøvede. Damen følte noget ubehageligt i hjertekulen, som hun var berettiget til at anse for medlidenhed; det var en ubeslutsom, lammende følelse. Efter nogen tavshed sagde herren til hende: 'De tunge lastvogne, der bruges her, har for stor bremselængde.' Damen følte sig lettet og takkede med et opmærksomt blik. Hun havde jo nok sommetider hørt dette ord men vidste ikke, hvad en bremselængde var, og ville heller ikke vide det; det var tilstrækkeligt for hende, at denne frygtelige begivenhed dermed kunne indføjes i en eller anden orden og blev til et teknisk problem, der ikke umiddelbart angik hende længere. $\mathrm{Nu}$ hørte man også en ambulances skingre fløjte, og dens hurtige ankomst fyldte alle de ventende med tilfredshed [...] Man gik næsten derfra med det berettigede indtryk, at en lovbundet og ordensmæssig begivenhed havde fundet sted. 'Ifølge de amerikanske statistikker,' bemærkede herren, 'dræbes der årligt 190.000 personer derovre ved bilulykker, mens 450.000 kvæstes.' (Musil 1994, 1/14-15).

Den ulykke som damen og hendes ledsager er vidne til er netop en rebelsk singularitet, en lastvogn, der springer ud af række og slår på tværs i byens ubestemte mylder. Denne begivenhed afføder en ubeslutsom, lammende følelse hos damen, som hun ikke umiddelbart kan indføje i nogen kendt orden; dog kun lige indtil herren kommer hende til undsætning med det forløsénde "bremselængde", der suger al den ubeslutsomme og lammende tavshed hun føler i forhold til ulykken ind i et forklarende begreb. Begivenheden indføjes i en orden i kraft af ordets sløring af de omstændigheder, der ledsager den. Det bliver helt grotesk, da herren til sidst opløser det sketes singularitet i det mest almene man kan forestille sig, nemlig en statistik over dræbte ved bilulykker. Med denne scene peger Musil på, at vi ikke har noget virkeligt begreb for det der springer ud af række, for det singulære; og alligevel indordner vi det eller repræsenterer det $\mathrm{i}$ et slags system. Byen er den scene, hvor vi på alle planer er vidne til dette besynderlige paradox.

\section{Det virtuelle Wien}

For Musil er Wien ikke kun midtpunkt i den anakronistiske statsdannelse „Det Østrig-ungarske dobbeltmonarki”, der gik i opløsning i 1918, men i lige så høj grad gennemgangsled til og en refleks af den moderne verden. Hans wiener bybillede er i sin relativitet og ubestemthed ikke nogen særlig præcis topografi. Det hedder i romanen således ofte en kirke, en plads, en park osv. Denne ubestemthed sker til fordel for en litterær gennemtrangning af byen, der fremmer de træk, som ikke handler om det bestemte, det lokalt fikserbare, men om det, der er fælles for alle storbyer.

Wiens langsomme byatmosfære drejes af Musil over gevind og omplantes til et eksperimentelt landskab, ${ }^{12}$ til et forsøgsfelt for brugen af konjunktiven ${ }^{13}$ og af den meget vigtige retoriske figur lignelsen, hvor på den ene side det faktiske og det imaginære perspektiv på byen lejrer ind over hinanden, og hvor på den anden side den imaginære gennemtrængning af byen forbinder sig med fortælletekniske manøvre.

Musils litterære Wien er komponeret som et spændingsfelt mellem og en dobbelthed af en imaginær overamerikansk eller futuristisk bys fantastiske tempo og funktionelle opdeling, der samtidig er sted for den mest ekstreme modernitet, og så det monumentale, anakronistiske Wien. Først den overamerikanske by:

I den alder, hvor man endnu tager alle skrædder-og barberanliggender højtideligt og holder af at se i spejlet, forestiller man sig ofte et sted, hvor man gerne ville tilbringe livet, eller i det mindste et sted, hvor det ville have stil at opholde sig, selvom man føler, at man for sit vedkommende ikke ligefrem gerne ville være der. En sådan social tvangsforestilling har nu i lang tid været en slags overamerikansk by, hvor alle iler eller står stille med stopuret $i$ hånden. Luft og jord er en myretue gennemskåret af færdselsårenes etager. Lufttog, jordtog, underjordstog, rørpostmenneskeforsendelser, automobilkæder suser horisontalt, hurtigelevatorer 
pumper vertikalt menneskemasser fra ét trafikplan til et andet; ved knudepunkterne springer man fra ét bevægelsesapparat over i et andet, suges uden omtanke ind og rives med af dets rytme, som udgør en synkope, en pause, en lille kløft på tyve sekunder mellem to brølende hastigheder, veksler hurtigt et par ord med hinanden i intervallerne $i$ denne almene rytme. Spørgsmål og svar griber ind $\mathrm{i}$ hinanden som maskinled, hvert menneske har kun ganske bestemte opgaver, erhvervene er samlet i grupper på bestemt steder, man spiser mens man er i bevægelse, forlystelserne er samlet i andre bydele, og andre steder igen står de tårne, hvor man finder kone, familie, grammofon og sjæl. Spænding og afspænding, virksomhed og kærlighed bliver tidsmæssigt nøjagtigt adskilt og afvejet efter grundig laboratorieerfaring (Musil 1994, 1/3637).

og dernæst det anakronistiske Wien (eller Kakanien som Musil fandt på at kalde dobbeltmonarkiet):

Dér i Kakanien, denne siden hen undergangne, uforståede stat, som i så mange henseender var forbilledlig uden at vinde anerkendelse for det var der også tempo, men ikke for meget tempo. Hver gang man i udlandet tænkte på dette land, foresvævede en erindringen om de hvide, brede, velhavende veje fra fodmarchernes og ekstraposternes tid, der som floder af orden, som bånd af lyst soldaterdrejl strakte sig gennem det $\mathrm{i}$ alle retninger og omslyngede landene med administrationens papirhvide arm [...] Naturligvis rullede der også automobiler på disse veje men ikke for mange automobiler! Man forberedte erobringen af luften også her; men ikke for intensivt. Man lod nu og da et skib sejle til Sydamerika eller Østasien; men ikke for ofte. Man havde ingen ambition om verdensmarked og verdensmagt; man sad i Europas midtpunkt, hvor de gamle verdensakser skærer hinanden; ordene koloni og oversøisk hørte man på som noget endnu helt uprøvet og fjernt [...] Også hovedstaden var noget mindre end alle alle andre landes største byer, men dog ikke så lidt større end blotte storstæder (Musil 1994, 1/37-38).

Wien anno 1913 og den imaginære amerikanske storby forbinder sig til det dobbeltperspektiv, der i sidste ende karakteriserer $\mathrm{Mu}-$ sils litterære iscenesættelse af Wien. ${ }^{14}$

Forsøgsvis kunne man måske forbinde disse to perspektiver med to begreber, hentet fra den franske litteraturforsker J. Y. Tadié, nemlig henholdsvis byroman og romanby. ${ }^{15}$ Byroman knytter sig til storbyen som et erfaringsrum, sted for moderniteten, på en måde, hvor byen forbliver en slags ramme for romanhandlingen, en baggrund eller ligefrem hovedperson. I byromanen er det afgørende således den affinitet, der nødvendigvis må være mellem byens sociale, arkitektoniske struktur og selve romanstrukturen. Romanby betegner derimod en yderligere overskridelse eller litterær gennemtrængning af byrummet til fordel for alle de ikkevirkeliggjorte eller virtuelle byer midt $\mathrm{i}$ byen. En metamorfose eller defigurering af byen som led i en mere overordnet bestræbelse. Det er denne dobbelthed man må have for øje i forbindelse med Musils litterære iscenesættelse af Wien.

\section{Linie og arabesk}

Jeg skal til sidst antyde, hvorledes Ulrichs personlige dannelse eller hans forfølgelsen af de mange singulariteter i byrummet forbinder sig med en bestemt skriftstrategi. I kap. 122 følger vi hovedpersonen Ulrich på vej hjemad gennem byens rum. Her udfoldes en række af Ulrich centrale refleksioner foranlediget af konfrontationen med Wien en fredfyldt aftenstund.

For en tid synes den rolige og fredfyldte byatmosfære at fremkalde en illusion om livets næsten landlige eller provinsielle overskuelighed:

Han befandt sig nu ved en af de træplantninger, der som en afbrudt ring følger den linie, hvor tidligere voldene lå, og havde kunnet gå igennem den med få skridt, men den store stribe himmel, der strakte sig på langs over træerne, lokkede ham til at dreje af og følge en retning, hvorved han hele tiden og uden at komme nærmere syntes at nærme sig den lyskrans, der virkede så umådelig privat og himmelsk tilbagetrukket svævede om de vinterlige parkanlæg, han vandrede igennem. 'Det er en slags intellektuel forkortelse, et sjæleligt perspektiv, som resulterer i denne hver aften tilbagevendende fred, en fred der strækker sig fra den ene dag til den anden og derved fremkalder den varige følelse af et liv i harmoni med sig selv,' tænkte han. 'Thi den vigtigste forudsætning for lykken er jo, kvantitativt set, ikke at udjævne modsætninger, men at få dem til at forsvinde på samme måde, som mellemrummene mellem træerne lukker sig, når man ser ned ad en lang allé. Og ganske ligesom de synlige forhold overalt forskydes for øjet, så at der opstår et af dette behersket billede, hvor det påtrængende og nære viser sig stort, men læn- 
gere borte selv det uhyrlige småt, huller lukker sig og det hele endelig modtager en smuk og jævn afrunding, sker det med de usynlige forhold, der i så høj grad forskydes af forstand og følelse, at der ubevidst opstår noget, hvori man føler sig som herre i huset (Musil 1969-71, 2/648-49).

Men Ulrich vægrer sig mod denne illusion, som kaldes en "forstandens perspektiviske forkortning", eller forkortning af sanserne, der kendetegner det provinsielle sindelags stædige fastholdelse af det antropocentriske verdensbillede. Det interessante ved dette sted i romanen er, at det forkortede livsprincip forbinder sig med en traditionel fortællestrategi, med „epikkens evige kunstgreb" eller "fortællingens tråd”, der sammenbinder heterogene elementer i et ordentligt, afrundet hele:

Og som en af de tilsyneladende afsidesliggende og abstrakte tanker, der så ofte fik direkte betydning $i$ hans liv, faldt det ham ind, at den livets lov, som man længes efter, overbebyrdet som man er, samtidig med at man drømmer om enkelthed, ikke varnogen anden end den fortællende ordens! Hin enkle orden, der består $i$, at man kan sige: 'Da dette var hændt, skete der hint!' Det, som beroliger os, er den enkle rækkefølge, afbildningen af livets overvældende mangfoldighed i en, som en matematiker ville sige, unidimensional orden; at trække alt det, der er sket $i$ tid og rum, som perler på en snor, netop hin berømte 'fortællingens tråd', af hvilken nu altså også livstråden består. Held den, der kan sige 'da', 'før' og 'bagefter'! Han kan have været ude for noget slemt, eller han kan have vredet sig i smerte, men så snart han er i stand til at gengive begivenhederne i deres tidsmæssige forløbs rækkefølge, følger han sig så vel, som om solen skinnede på hans mave. Det er dette, som romanen kunstigt har benyttet sig af: den rejsende rider måske i øsregn ad landevejen eller stamper i tyve graders kulde gennem den knirkende sne, læseren bliver behageligt til mode, og det ville være svært at fatte, hvis dette epikkens evige kunstgreb, som allerede barnepigerne beroliger de små med, denne bedst prøvede og og dokumenterede 'intellektuelle forkortelse af perspektivet', ikke skulle høre til livet selv. De fleste mennesker er fortællere i det fundamentale forhold til sig selv. De elsker ikke lyrikken, i hvert fald kun i korte øjeblikke, og selv om der i livets tråd knyttes en smule 'fordi', og 'for at', afskyer menneskene dog enhver spekulation, der strækker sig videre end til dette. De holder af det ordnede Nacheinander af fakta, fordi det ligner en nødvendighed, og føler sig ligesom i sikkerhed midt i kaos gennem det indtryk, at deres liv har et 'løb'. Og Ulrich bemærkede nu, at han havde mistet dette primitivt episke, som det private liv endnu holder fast ved, selv om i det offent- lige alting allerede er blevet ikke-fortællende og ikke længere følger en 'tråd', men udbreder sig i en uendeligt sammenvævet flade (Musil 1969$71,2 / 650)$.

Ulrich afspejler i modsætning til føromtalte forkortede livsprincip den mest ekstreme modernitetserfaring, hvor byrummet i den litterære iscenesættelse taber sine faste koordinater og bliver til det, den tyske musilforsker Gerhart Baumann har kaldt et romanfelt, 16 hvor alt ses som afhængige funktioner af hinanden og af et hele. Og hvor mennesket ikke kan tildeles nogen priviligeret position. Her bliver det vel at mærke igen muligt at tilskrive det singulære eller det tilfældige en betydning for det overordnede felt, i og med at det ikke på forhånd er determineret eller underkastet en orden

Ulrich er en flanør i storbyen. Med ham slyngrer livstråden sig gennem tilfældighederne: dvs. det han støder på i byen og de refleksioner det foranlediger. Hans slyngede omveje i byens rum tegner den „uendeligt sammenvævede flade”s arabesk. Arabesken er at forstå som en slags dramatisering eller virtualisering af den lige linie, af tråden. ${ }^{17}$ Arabesken er labyrintisk, fordi dens endelige form og dens midtpunkt ikke er forudsigeligt, men frembringes via den slyngede omvej. En omvej, hvor der afprøves nye sammenhænge mellem det singulære og det almene.

Musils begreb om det moderne er en arabesk, fordi det bestående rums grænser og.linier ikke overskrides eller afskæres, men slynges og dramatiseres på en ny måde. Byen bliver i hans roman til en arabesk. 


\section{Noter}

1. Der citeres i artiklen fra følgende to udgaver af Musils Manden uden egenskaber: Karsten Sand Iversens oversættelse fra 1994 (Musil 1994, bind/sidehenvisning) og Mogens Boisens oversættelse fra 1969-71 (Musil 1969-71, bind/sidehenvisning)

2. Svend Erik Larsen har i foredraget „Kan litteraturen se byen” (holdt i forbindelse med fored ragsrække på Institut for Litteraturhistorie marts 1995) blandt andet tematiseret denne figur i forbindelse med litterære bybeskrivelser, emblematisk repræsenteret med tårnet og gaden i forlængelse af Jens Baggesens roman Labyrinten.

3. Denne efterhånden meget udbredte og alment accepterede læsning af romanens første kapitel diskuteres af så forskellige Musilforskere som Hans-Georg. Pott, der i Musil, München 1984 bruger sondringen mellem den videnskabelige og den hverdagslige diskurs til mere generelt at karakterisere en litterær strategi hos Musil, Marianne Charriere-Jaquin der i „Der Mann ohne Eigenschaften als Suche nach einer hermaphroditischen Sprache. Wechselspiel des Konvexen und Konkaven", i MusilsStudien 15, München 1987, der gør den iagttagelse, at den videnskabelige diskurs overtager den hverdagslige diskurs' antropomorfe træk og endelig Frederik Tygstrup, der blandt andet i artiklen „P Punkt, linie, flade" (i Kultur \& Klasse 76 (1994)) analyserer betydningen af den videnskabelige diskurs' antropomorfisering for Musils litterære strategi.

4. Til dette parallelle perspektiv på romanens første kapitel, hvor de ikke blot fokuseres på forholdet mellem den hverdagslige og den videnskabelige diskurs, men også på forholdet mellem det singulære og det almene, skylder jeg en tak til deltagerne i mit undervisningsforløb om Robert Musil, efteråret 1994, i denne forbindelse navnlig til Morten Visby Poulsen og Sigurd Sørensen.

5. Analysen af det singulære og det almene kan ikke adskilles fra et filosofisk betinget mulighedsbegreb, som Musil i kritisk dialog . med blandt andre Leibniz og Kant udvikler til en litterær praksis og som i høj grad er knyttet til vores umiddelbare sansning og begribelse af omverdenen.

6. Jf. Michel Serres Hermes V (Le Passage du Nord-Ouest, Paris 1980)

7. ibid.

8. Jf. Musils essay „Ansätze zu neuer Ästhetik”

9. Fraspaltning er et centralt begreb i Musils ovennævnte skitse til en æstetik, der tager udgangspunkt i den ungarske filmteoretiker Béla Balázs' Der sichtbare Mensch.

10. Jf. filosoffen Arno Viktor Nielsen, der i artiklen „A Space Odyssey” beskæftiger sig med rummets filosofihistorie og i den sammenhæng er inde på rummets betydning i Machs fysik og filosofi.

11. Citeret fra Arno Victor Nielsen „A Space Odyssey”, s. 7-8.
12. Jf. Susanne Ledanff „Bildungsroman versus Großstadtroman”, i Sprache in technischen Zeitalter 78 (1981).

13. Se Albrecht Schönes 'klassiske', fremragende undersøgelse af Musils brug af konjunktiven „Zum Gebrach des Konjunktivs bei Robert Musil”, i Horst Schillermert (Hg.) Deutsche Romane von Grimmelhausen bis Musil, Frankfurt/M 1974.

14. Jf. Susanne Ledanff „Bildungsroman versus Großstadtroman”.

15. J. Y. Tadié Le Roman au XXe siècle, Paris 1990.

16. Jf. hans „romanhafter Feld” i Musil. Ein Entwurf, Bern/München 1981.

17. Se i den forbindelse Carsten Madsens fremragende læsning af arabesk-figuren i forbindelse med en analyse af J. P. Jacobsens digt „Arabesk til en Haandtegning af Michel Angelo", i Passage 16 (1994). 